\title{
VERHULST, Adriaan, Anfänge des Städtewesens an Schelde, Maas und Rhein bis zum Jahre 1000
}

\section{Étienne Champion}

\section{(2) OpenEdition}

\section{Journals}

Édition électronique

URL : http://journals.openedition.org/ifha/1467

DOl : 10.4000/ifha. 1467

ISSN : 2198-8943

Éditeur

IFRA - Institut franco-allemand (sciences historiques et sociales)

Référence électronique

Étienne Champion, «VERHULST, Adriaan, Anfänge des Städtewesens an Schelde, Maas und Rhein bis zum Jahre $1000 »$, Revue de l'IFHA [En ligne], Date de recension, mis en ligne le 01 janvier 1998, consulté le 22 septembre 2020. URL : http://journals.openedition.org/ifha/1467 ; DOI : https://doi.org/ 10.4000/ifha. 1467

Ce document a été généré automatiquement le 22 septembre 2020.

(C)IFHA 


\title{
VERHULST, Adriaan, Anfänge des Städtewesens an Schelde, Maas und Rhein bis zum Jahre 1000
}

\author{
Étienne Champion
}

1 De ce volume sur les débuts de l'urbanisation entre Escaut, Meuse et Rhin, le lecteur ne doit pas attendre d'apports scientifiques nouveaux: aucun article inédit ne s'y trouve publié. Pourtant, parce qu'aucune synthèse récente n'est disponible sur le sujet et parce qu'il comprend une bibliographie sélective établie et commentée par A.V., ce livre s'impose comme un outil de travail précieux, d'autant que les paginations originales sont scrupuleusement indiquées. Sur les dix-huit articles sélectionnés, neuf sont en allemand, huit en français, un en anglais. On ne résumera bien sûr pas ces textes; nombre d'entre eux sont célèbres. Citons l'article de 1958 de Franz PETRI sur »Die Anfänge des Städtwesens in den Niederlanden und dem angrenzenden Frankreich«ou, en français, celui de J. DHONDT sur Quentovic (1962). Cette compilation est enrichissante qui remet en perspective l'évolution de l'historiographie sur la voie tracée par les travaux pionniers d'H. Pirenne. Certes sa principale thèse, laquelle défendait une émergence urbaine postérieure à l'an mil liée à la croissance du grand commerce a été remise en cause. Archéologie, topographie, numismatique ont largement renouvelé l'analyse des prodromes de l'urbanisation. Pourtant cet ouvrage prouve l'ampleur de la dette envers l'historien mort en 1935: la réflexion sur la genèse des villes d'Europe du nord, souvent animée par ses fils et petits-fils spirituels s'est largement déterminée pour ou contre lui, c'est à dire finalement, autour de lui.

2 Étienne CHAMPION 